\title{
Vibrio communis sp. nov., isolated from the marine animals Mussismilia hispida, Phyllogorgia dilatata, Palythoa caribaeorum, Palythoa variabilis and Litopenaeus vannamei
}

Correspondence

Fabiano L. Thompson

fabiano.thompson@biologia.ufrj.br
Luciane A. Chimetto, ${ }^{1,2,3}$ Ilse Cleenwerck, ${ }^{3}$ Nelson Alves, Jr, ${ }^{2}$ Bruno Sergio Silva, ${ }^{2}$ Marcelo Brocchi, ${ }^{1}$ Anne Willems, ${ }^{4}$ Paul De Vos ${ }^{3,4}$ and Fabiano L. Thompson ${ }^{2}$

${ }^{1}$ Department of Genetics, Evolution and Bioagents, Biology Institute, State University of Campinas (UNICAMP), Campinas, Brazil

${ }^{2}$ Department of Genetics, Institute of Biology, Federal University of Rio de Janeiro (UFRJ), Rio de Janeiro, Brazil

${ }^{3}$ BCCM/LMG Bacteria Collection, Ghent University, K. L. Ledeganckstraat 35, B-9000 Ghent, Belgium

${ }^{4}$ Laboratory of Microbiology, Faculty of Sciences, Ghent University, K. L. Ledeganckstraat 35, B-9000 Ghent, Belgium

Eight Vibrio isolates originating from the marine corals Mussismilia hispida and Phyllogorgia dilatata and the zoanthids Palythoa caribaeorum and Palythoa variabilis in Brazil and the Pacific white shrimp (Litopenaeus vannamei) in Ecuador were studied by means of a polyphasic approach. The novel isolates formed a tight monophyletic group in the genus Vibrio and were closely related to species of the Vibrio harveyi group, to which they showed more than 99\% 16S rRNA gene sequence similarity. Analysis based on concatenated sequences of the following seven genes, $16 \mathrm{~S}$ rRNA, gyrB, recA, rpoA, topA, pyrH and $m r e B$ (5633 bp in length), showed clear separation between the isolates and species of the $V$. harveyi group. Amplified fragment length polymorphism (AFLP) analysis, performed previously, revealed that a representative isolate of this group, LMG 20370, was clearly separate from known Vibrio species (it belonged to the so-called AFLP cluster A31). DNA-DNA hybridization (DDH) experiments with representative isolates and type strains of the $V$. harveyi species group revealed high DDH between the novel isolates (more than $74 \%$ ) and less than $70 \% \mathrm{DDH}$ towards type strains of related Vibrio species, proving the novel species status of the isolates. Phenotypically, the novel species belongs to the arginine dihydrolase (A)-negative, lysine decarboxylase $(\mathrm{L})$-positive and ornithine decarboxylase $(\mathrm{O})$-positive $(\mathrm{A}-\mathrm{L}+/ \mathrm{O}+)$ cluster reported previously. Most species of the $V$. harveyi group (i.e. Vibrio rotiferianus, $V$. harveyi, $V$. parahaemolyticus and $V$. alginolyticus) also belong to this $A-/ L+/ O+$ cluster. However, several phenotypic features can be used for the identification of the novel species. In contrast to its closest phylogenetic neighbours, the novel species exhibits esterase (C4) and $N$-acetyl- $\beta$ glucosaminidase activities, but it does not produce acetoin, does not use citrate, $\alpha$-ketoglutaric acid or propionic acid and does not ferment melibiose. The novel species can also be differentiated on the basis of the presence of the fatty acids $C_{17: 0}, C_{17: 1} \omega 8 c$, iso- $C_{17: 0}$ and iso- $C_{13: 0}$ and the absence of the fatty acid $\mathrm{C}_{18: 0}$. The name Vibrio communis sp. nov. is proposed for this taxon.

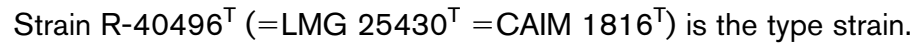

Abbreviations: AFLP, amplified fragment length polymorphism; DDH, DNA-DNA hybridization; MLSA, multilocus sequence analysis.

The GenBank/EMBL/DDBJ accession numbers for the sequences of strains of Vibrio communis sp. nov. determined in this study are GU078670GU078676 and AJ345066 (16S rRNA gene), GU078680-GU078684 (gyrB), GU078693-GU078696, EU717055 and EF596446 (recA), GU078697-GU078703 and AJ842625 (rpoA), GU078704-GU078710 (topA), GU078691, GU078692, EU251617, EU251620, EU251630, EU251638, EU716913 and EF596375 (pyrH) and GU078685-GU078690 (mreB), as detailed in Supplementary Table S1.

Five supplementary tables and eight supplementary figures are available with the online version of this paper. 
The family Vibrionaceae belongs to the Gammaproteobacteria and at the time of writing includes six genera: Vibrio (Baumann \& Schubert, 1984), Photobacterium (Baumann \& Baumann, 1984), Salinivibrio (Mellado et al., 1996), Grimontia (Thompson et al., 2003), Enterovibrio (Thompson et al., 2002b) and Alivivibrio (Urbanczyk et al., 2007). The family includes over 115 formally described species (http://www.vibriobiology.net/). Vibrios are common inhabitants of aquatic environments, especially the ocean, and they are known to live either freely or associated as symbionts with aquatic animals in marine or estuarine waters or as parasites of fish, crustaceans and molluscs (Thompson et al., 2004). Vibrios appear to have a key role in the health of corals (Rosenberg et al., 2007). They may provide protection against pathogens or contribute to nitrogen fixation within the holobiont (Ritchie, 2006; Olson et al., 2009). Vibrio harveyi, V. campbellii, $V$. rotiferianus, $V$. alginolyticus, $V$. parahaemolyticus, $V$. natriegens and $V$. mytili are members of the Vibrio core group (Dorsch et al., 1992), later called the Harveyi clade (Sawabe et al., 2007b). Recently, Vibrio azureus was included in this group (Yoshizawa et al., 2009). Bacteria of this clade have been found associated with coral disease, as in yellow band disease, which is one of the most significant coral diseases of the tropics (Cervino et al., 2008). Members of the Vibrio core group have been described as closely related by $16 \mathrm{~S}$ rRNA gene sequence analysis and, in some cases, are indistinguishable by more than 100 phenotypic features. For instance, several isolates phenotypically identified as $V$. harveyi were in fact shown to be members of $V$. campbellii by means of molecular identification and DNA-DNA hybridization (DDH) (Gomez-Gil et al., 2004). Multilocus sequence analysis (MLSA) has become an important methodology for studying the taxonomy of Vibrio. It has greatly improved species identification and classification (Thompson et al., 2005, 2007; Sawabe et al., 2007b) and is now widely applied (Sawabe et al., 2007a; Gomez-Gil et al., 2008; Rameshkumar et al., 2008; Beaz Hidalgo et al., 2009; Yoshizawa et al., 2009; Xu et al., 2009; Wang et al., 2010).

In a recent study aimed at the taxonomic characterization of vibrios associated with corals in Brazil, several isolates potentially belonging to a novel species were obtained (Chimetto et al., 2008, 2009; Alves et al., 2010). These isolates formed a large, tight group (named L1 or V. harveyilike) on the basis of $p y r H$ gene sequences and were closely related to strain LMG 20370. This strain was reported in a previous study as a separated group, amplified fragment length polymorphism (AFLP) cluster A31, within the Vibrio group (Thompson et al., 2001b). In the present study, a detailed polyphasic taxonomic analysis was performed in order to determine the exact taxonomic position of a representative group of eight novel isolates, including LMG 20370 and seven Brazilian isolates.

The eight isolates originated from different places over a period of time (Table 1) and were obtained as described previously (Chimetto et al., 2008, 2009). Sequences of genes encoding the $16 \mathrm{~S}$ rRNA, recombination repair protein
( $r e c A)$, topoisomerase I (topA), actin-like cytoskeleton protein $(m r e B)$, RNA polymerase alpha subunit $(r p o A)$, DNA gyrase B subunit $(g y r B)$ and uridylate kinase ( $p y r H)$ were obtained as described previously (Thompson et al., 2001b, 2007; Sawabe et al., 2007b). Briefly, PCR products were purified with the enzyme Exosap according to the instructions of the manufacturer (GE Health Care). Subsequently, $5 \mu$ purified PCR products was mixed with $4 \mu \mathrm{l}$ ET Terminator Mix (GE Health Care), $0.6 \mu \mathrm{l}$ sequencing primers $\left(20 \mu \mathrm{mol}^{-1}\right)$ and $0.4 \mu \mathrm{l}$ Milli-Q water. The thermal program consisted of 30 cycles of $20 \mathrm{~s}$ at $95{ }^{\circ} \mathrm{C}, 15 \mathrm{~s}$ at $50{ }^{\circ} \mathrm{C}$ and $1 \mathrm{~min}$ at $60{ }^{\circ} \mathrm{C}$. Purification of the sequencing products was done by adding $1 \mu \mathrm{l}$ ammonium acetate $\left(7.5 \mathrm{~mol} \mathrm{l}^{-1}\right.$ ) and $27.5 \mu \mathrm{l}$ absolute ethanol to each product, incubating the mixture in the dark for $30 \mathrm{~min}$ and subsequently centrifuging at $20800 \mathrm{~g}$ for $75 \mathrm{~min}$ at $4{ }^{\circ} \mathrm{C}$. After this, the supernatant was removed and $100 \mu \mathrm{l} 70 \%$ ethanol was added. A last centrifugation step was performed at 3700 r.p.m. for $45 \mathrm{~min}$ at $4{ }^{\circ} \mathrm{C}$. Separation of the DNA fragments was performed using the MegaBace 1000 system (GE Health Care). Voltage and time of injection were $3 \mathrm{kV}$ and $80 \mathrm{~s}$. Electrophoresis was performed at $9 \mathrm{kV}$ for $100 \mathrm{~min}$ at $44{ }^{\circ} \mathrm{C}$. Raw sequence data were transferred to ChromasPro version 1.34 (Technelysium Pty Ltd), where consensus sequences were determined. Sequences were aligned using CLUSTAL w. Pairwise similarity was calculated with the BioNumerics 4.5 software package (Applied Maths), using an open gap penalty of $100 \%$ and a unit gap penalty of $0 \%$. Similarity matrices and phylogenetic trees were constructed using the MEGA software version 4.0 (Tamura et al., 2007). Trees were drawn using the neighbour-joining (Saitou \& Nei, 1987) and maximum-parsimony (Eck \& Dayhoff, 1966) methods. The robustness of each topology was checked by 1000 bootstrap replications (Felsenstein, 1985). The gene sequence data obtained in this study are also available through the Taxvibrio website (http://www.taxvibrio.lncc.br/). The GenBank accession numbers for the $16 \mathrm{~S}$ rRNA, gyrB, recA, rpoA, topA, pyrH and $m r e B$ gene sequences obtained in this study are listed in Supplementary Table S1, available in IJSEM Online. DDH experiments were performed using the microplate method as described in detail previously (Ezaki et al., 1989; Willems et al., 2001). The hybridization temperature was $40{ }^{\circ} \mathrm{C}$ in the presence of $50 \%$ formamide. Reciprocal reactions were performed for every DNA pair and their variation was within the limits of this method (Goris et al., 1998). DDH experiments were performed in four replicates. The $\mathrm{G}+\mathrm{C}$ content of DNA was determined by the HPLC method as described previously (Mesbah et al., 1989). Analysis of fatty acid methyl esters was carried out as described by Huys et al. (1994). For fatty acid analysis, cells were grown on TSA (Difco) supplemented with $1.5 \% \mathrm{NaCl}$ for $24 \mathrm{~h}$ at $28{ }^{\circ} \mathrm{C}$. Catalase activity was determined by adding young cells to a drop of $3 \% \mathrm{H}_{2} \mathrm{O}_{2}$ solution and observation of bubble production. Oxidase activity was tested using $1 \% \quad N, N, N^{\prime}, N^{\prime}$-tetramethyl $p$ phenylenediamine (Kovács, 1956). Phenotypic characterization was performed using API ZYM and API 20E strips (bioMérieux) and the Biolog GN2 metabolic fingerprinting kit as described previously (Thompson et al., 2001a, 2002a). 
Table 1. Isolates of Vibrio communis sp. nov.

\begin{tabular}{|c|c|c|c|}
\hline Isolate & Source & Locality & Year \\
\hline $\mathrm{R}-40496^{\mathrm{T}}\left(=\mathrm{LMG} 25430^{\mathrm{T}}=\mathrm{CAIM} 1816^{\mathrm{T}}\right)$ & $\begin{array}{l}\text { Mucus of apparently healthy } \\
\text { Mussismilia hispida }\end{array}$ & $\begin{array}{l}\text { Grande beach in São Sebastião } \\
\text { Channel, São Paulo, Brazil }\end{array}$ & 2005 \\
\hline R-40498 (=LMG 25431) & As above & As above & 2005 \\
\hline $\mathrm{R}-40501$ & $\begin{array}{l}\text { Mucus of apparently healthy } \\
\text { Palythoa caribaeorum }\end{array}$ & $\begin{array}{l}\text { Preta beach in São Sebastião } \\
\text { Channel, São Paulo, Brazil }\end{array}$ & 2005 \\
\hline R-40504 & $\begin{array}{l}\text { Mucus of apparently healthy } \\
\text { Palythoa variabilis }\end{array}$ & $\begin{array}{l}\text { Portinho beach in São Sebastião } \\
\text { Channel, São Paulo, Brazil }\end{array}$ & 2005 \\
\hline R-40506 (=LMG 25432) & Mucus of apparently healthy Mussismilia hispida & As above & 2006 \\
\hline R-40900 & As above & Abrolhos Bank, Bahia, Brazil & 2007 \\
\hline R-40901 (=LMG 25433) & Mucus of apparently healthy Phyllogorgia dilatata & As above & 2007 \\
\hline LMG 20370 & $\begin{array}{l}\text { Digestive gland of white shrimp (Litopenaeus } \\
\text { vannamei) }\end{array}$ & CENAIM (Ecuador) & 2000 \\
\hline
\end{tabular}

The following type strains of phylogenetically closely related Vibrio species were included in the phenotypic analyses: $V$. rotiferianus LMG $21460^{\mathrm{T}}, V$. harveyi LMG $4044^{\mathrm{T}}, V$. parahaemolyticus LMG $2850^{\mathrm{T}}$, V. alginolyticus LMG $4409^{\mathrm{T}}$, $V$. campbellii LMG $11216^{\mathrm{T}}$, V. natriegens LMG $10935^{\mathrm{T}}$ and $V$. azureus LMG $25266^{\mathrm{T}}$. The temperature range for growth was determined by incubation on tryptone soy agar (TSA; Oxoid) supplemented with $2 \% \mathrm{NaCl}(\mathrm{w} / \mathrm{v})$ at $0-42{ }^{\circ} \mathrm{C}$. Growth at 0 $10 \%(\mathrm{w} / \mathrm{v}) \mathrm{NaCl}$ was assessed by incubation on TSA (Oxoid) supplemented with $\mathrm{NaCl}$ for $72 \mathrm{~h}$ at $28{ }^{\circ} \mathrm{C}$.

Phylogenetic analyses based on the 16S rRNA gene sequence classified the eight isolates in a tight monophyletic group in the genus Vibrio (Fig. 1). The eight isolates R-40496 ${ }^{\mathrm{T}}$, R-40498, R-40501, R-40504, R-40508, R-40900, R-40901 and LMG 20370 showed more than 99.8\% mutual 16S rRNA gene sequence similarity. They were most closely related to species of the $V$. harveyi group (Reichelt \& Baumann, 1973), also called the Vibrio core group (Dorsch et al., 1992) or the Harveyi clade (Sawabe et al., 2007b). Phylogenetic analysis with the maximumparsimony method produced results congruent to those obtained with the neighbour-joining method (Supplementary Fig. S1). The $16 \mathrm{~S}$ rRNA gene sequence similarity of the isolates towards their closest phylogenetic neighbours varied between $99.5 \%$ for $V$. rotiferianus LMG $21460^{\mathrm{T}}$ and $98.8 \%$ for $V$. mytili CECT $632^{\mathrm{T}}$ (Supplementary Table S2). Trees based on housekeeping genes $(g y r B, \operatorname{rec} A, r p o A, t o p A, p y r H$ and $m r e B)$ confirmed the tight grouping of the novel isolates (Supplementary Figs S2-S7). Similarities between the novel isolates were 97.498.9\% for $g y r B, 98.3-99.6 \%$ for $r e c A, 99.4-100 \%$ for $r p o A$, 97.0-99.5\% for topA, 98.5-99.8\% for $p y r H$ and 95.5$97.7 \%$ for $m r e B$. Similarities between representative strain $\mathrm{R}-40496^{\mathrm{T}}$ and the type strains of the phylogenetically closest species of the $V$. harveyi group were $83.9-91.7 \%$ for gyrB, 89.0-98.3\% for $r e c A, 95.8-98.3 \%$ for $r p o A, 80.7-$ 90.7\% for topA, 87.5-96.3\% for $p y r H$ and $86.4-96.5 \%$ for $m r e B$ (Supplementary Table S2). These data indicate that the isolates belong to a novel species in the $V$. harveyi group, since the gyrB, rpoA, top $A$ and $p y r H$ gene sequences have high phylogenetic resolution for species identification within the genus Vibrio (Thompson et al., 2005, 2007). MLSA of concatenated 16S rRNA, rpoA and pyrH gene sequences confirmed the tight grouping of the eight isolates (Fig. 2) and a similar result was obtained by MLSA of concatenated 16S rRNA, gyrB, recA, rpoA, topA, pyrH and $m r e B$ gene sequences (Supplementary Fig. S8). The MLSA data confirmed that the eight isolates belong to a novel species within the genus Vibrio.

$\mathrm{DDH}$ experiments were performed with representative strains of the novel group and the type strains of the closest phylogenetic neighbours in order to prove that the isolates belong to a novel species (Supplementary Table S3). The representative strains showed less than $70 \% \mathrm{DDH}$ with $V$. harveyi LMG $4044^{\mathrm{T}}, V$. campbellii LMG $11216^{\mathrm{T}}$, $V$. rotiferianus $\mathrm{LMG} 21460^{\mathrm{T}}$, $V$. parahaemolyticus LMG $2850^{\mathrm{T}}, V$. alginolyticus LMG $4409^{\mathrm{T}}, V$. natriegens LMG $10935^{\mathrm{T}}$ and $V$. azureus LMG $25266^{\mathrm{T}}$. DDH between the novel isolates varied between 74 and $86 \%$. DDH between LMG 20370 and $V$. harveyi LMG $4044^{\mathrm{T}}$ was $66 \%$, whereas DDH between LMG 20370 and R-40496 ${ }^{\mathrm{T}}$ was $79 \%$. Clearly, the $\mathrm{DDH}$ data prove that the eight new isolates represent a novel species.

Phenotypically, the eight isolates are assigned to the genus Vibrio (Alsina \& Blanch, 1994) and belong to the arginine dihydrolase (A)-negative, lysine decarboxylase (L)-positive and ornithine decarboxylase $(\mathrm{O})$-positive $(\mathrm{A}-/ \mathrm{L}+/ \mathrm{O}+)$ cluster (Noguerola \& Blanch, 2008). Based on 16S rRNA gene sequence comparisons and MLSA data, most of the phylogenetically related species, i.e. $V$. rotiferianus, $V$. harveyi, V. parahaemolyticus and $V$. alginolyticus, belong in the same phenotypic cluster $(\mathrm{A}-/ \mathrm{L}+/ \mathrm{O}+)$. However, $V$. campbellii and $V$. natriegens belong to the $\mathrm{A}-/ \mathrm{L}-/ \mathrm{O}-$ cluster and $V$. mytili belongs to the $\mathrm{A}+/ \mathrm{L}-/ \mathrm{O}-$ cluster according to Noguerola \& Blanch (2008). Several phenotypic features can be used to differentiate the novel species from its closest neighbours (Table 2). In contrast to its closest neighbours, the novel species exhibits esterase (C4) and $N$-acetyl- $\beta$-glucosaminidase activities, but it does not produce acetoin and does not utilize citrate, $\alpha$-ketoglutaric 


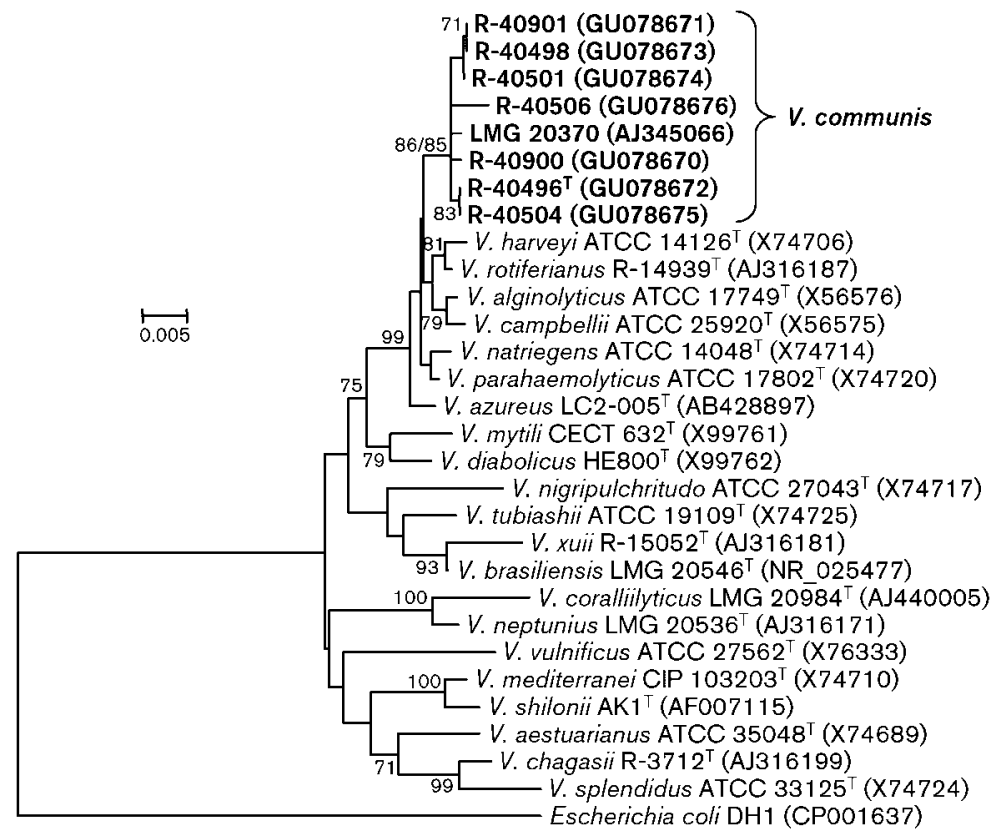

Fig. 1. Neighbour-joining phylogenetic tree showing the phylogenetic position of strains of Vibrio communis sp. nov. based on $16 \mathrm{~S}$ rRNA gene sequences (1470 bp). The optimal tree with the sum of branch lengths $=0.28450859$ is shown. Evolutionary distances were computed using the Jukes-Cantor method. All positions containing alignment gaps and missing data were eliminated only in pairwise sequence comparisons (pairwise deletion option). Bootstrap values ( $\geqslant 70 \%$ ) based on 1000 repetitions are shown. The bootstrap value for the $V$. communis branch was also computed by the maximum-parsimony method (neighbour-joining/maximum-parsimony). The sequence of Escherichia coli DH1 was used as an outgroup. Bar, $0.5 \%$ estimated sequence divergence. acid or propionic acid. It also does not ferment melibiose, but it ferments amygdalin and has weak growth on $8 \%$ $\mathrm{NaCl}$. Yellow colonies are observed on thiosulfate-citratebile salts-sucrose (TCBS) agar and beige, translucent colonies on marine agar. Phenotypic variation was observed among the isolates (Supplementary Table S4), suggesting a good representation of the phenotype of the novel species. The novel isolates can also be differentiated from their

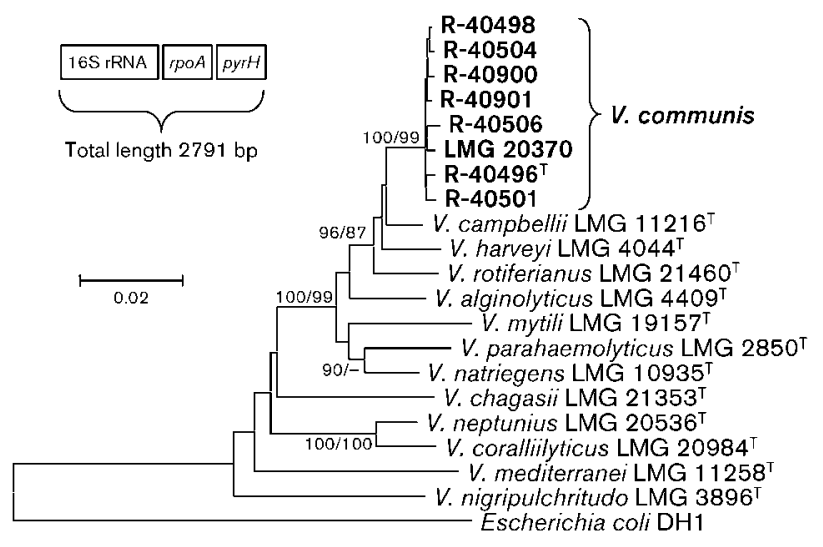

Fig. 2. Neighbour-joining phylogenetic tree showing the phylogenetic position of strains of $V$. communis sp. nov. based on concatenated 16S rRNA (1470 bp), rpoA (790 bp) and pyrH (531 bp) gene sequences. Evolutionary distances were computed using the Jukes-Cantor method. Phylogenetic analyses were conducted in MEGA4. Bootstrap values ( $>70 \%$ ) based on 1000 repetitions are shown. Numbers at nodes denote bootstrap values derived from the neighbour-joining/maximum-parsimony methods; ,$-<70 \%$. The sequence of Escherichia coli $\mathrm{DH} 1$ was used as an outgroup. Bar, $2 \%$ estimated sequence divergence. neighbours on the basis of the presence of the fatty acids $\mathrm{C}_{17: 0}, \mathrm{C}_{17: 1} \omega 8 c$, iso- $\mathrm{C}_{17: 0}$ and iso- $\mathrm{C}_{13: 0}$ and the absence of the fatty acid $\mathrm{C}_{18: 0}$, which is normally present in other species of the $V$. harveyi group (Supplementary Table S5).

Based on the polyphasic analysis presented in this study, we propose to classify the eight isolates in the novel species Vibrio communis sp. nov. The novel species can be differentiated from its phylogenetic neighbours by means of AFLP (Thompson et al., 2001b), MLSA, DDH and several phenotypic and chemotaxonomic tests.

\section{Description of Vibrio communis sp. nov.}

Vibrio communis (com.mu'nis. L. masc. adj. communis common, widespread, referring to the frequent isolation of the species in the marine environment).

Cells are Gram-negative, motile bacilli, $1 \mu \mathrm{m}$ wide and 2.5$3.5 \mu \mathrm{m}$ long. Catalase- and oxidase-positive. Forms translucent, convex, smooth-rounded colonies with entire margins, beige in colour and $1 \mathrm{~mm}$ in diameter after 1 day of incubation at $28{ }^{\circ} \mathrm{C}$ on TSA. Prolific growth occurs at $15-37{ }^{\circ} \mathrm{C}$ and at $0.5-6.0 \%(\mathrm{w} / \mathrm{v}) \mathrm{NaCl}$. Weak growth is observed in the presence of $8 \% \mathrm{NaCl}$. No growth is observed in the absence of $\mathrm{NaCl}$ or at or above $9 \% \mathrm{NaCl}$, at $7{ }^{\circ} \mathrm{C}$ or below or at $42{ }^{\circ} \mathrm{C}$ or above. Yellow colonies are observed on the selective medium TCBS. Positive for alkaline phosphatase, esterase (C4), esterase lipase (C8), lipase (C14), leucine arylamidase, valine arylamidase, trypsin, $\alpha$-chymotrypsin, acid phosphatase, naphthol-AS-BI-phosphohydrolase, $\beta$-galactosidase, $N$-acetyl- $\beta$-glucosaminidase, $\alpha$-glucosidase (except R-40498), lysine decarboxylase and ornithine decarboxylase (except R-40900) enzyme activities, production of indole and acetoin (Voges-Proskauer), fermentation of glucose, mannitol, sucrose and amygdalin, gelatinase diffusion 
Table 2. Differential phenotypic characteristics of strains of $V$. communis sp. nov. and related species of the genus Vibrio

Strains: 1, V. communis sp. nov. (eight strains); 2, V. rotiferianus LMG $21460^{\mathrm{T}}$; 3, V. harveyi LMG $4044^{\mathrm{T}}$; 4, V. parahaemolyticus LMG $2850^{\mathrm{T}}$; 5, V. alginolyticus LMG $4409^{\mathrm{T}} ; 6$, V. campbellii LMG $11216^{\mathrm{T}} ; 7$, V. natriegens LMG $10935^{\mathrm{T}}$; 8, V. azureus LMG $25266^{\mathrm{T}}$. +, Positive; -, negative; w, weakly positive. Data were obtained in this study. Species are assigned to phenotypic clusters according to Noguerola \& Blanch (2008); characteristics in bold are useful to differentiate $A-/ L+/ O+$ species according to Noguerola \& Blanch (2008).

\begin{tabular}{|c|c|c|c|c|c|c|c|c|}
\hline \multirow[t]{2}{*}{ Characteristic } & \multicolumn{5}{|c|}{$\mathrm{A}-/ \mathrm{L}+/ \mathrm{O}+$} & \multicolumn{3}{|c|}{$\mathrm{A}-/ \mathrm{L}-/ \mathrm{O}-$} \\
\hline & 1 & 2 & 3 & 4 & 5 & 6 & 7 & 8 \\
\hline \multicolumn{9}{|l|}{ Growth in $\mathrm{NaCl}$ at: } \\
\hline $8 \%(w / v)$ & $\mathrm{W}$ & - & - & + & + & $\mathrm{w}$ & + & - \\
\hline $10 \%(w / v)$ & - & - & - & - & + & - & - & - \\
\hline \multicolumn{9}{|l|}{ Production of: } \\
\hline Indole & + & + & + & + & + & + & - & - \\
\hline Acetoin & + & - & - & - & + & - & - & + \\
\hline \multicolumn{9}{|l|}{ Enzyme activities } \\
\hline Esterase (C4) & + & + & - & + & + & + & - & - \\
\hline Lipase (C14) & + & - & + & - & - & + & + & - \\
\hline$\beta$-Galactosidase & + & - & + & - & - & - & + & - \\
\hline$N$-Acetyl- $\beta$-glucosaminidase & + & - & - & + & + & + & - & + \\
\hline$\alpha$-Chymotrypsin & + & + & + & - & - & + & - & - \\
\hline Tryptophan deaminase & - & + & - & - & - & - & + & - \\
\hline Urea & - & + & - & - & - & - & + & - \\
\hline \multicolumn{9}{|l|}{ Utilization of: } \\
\hline L-Arabinose & - & + & - & + & - & $\mathrm{w}$ & + & - \\
\hline Citrate & - & - & + & - & - & - & + & - \\
\hline cis-Aconitic acid & - & - & + & $\mathrm{W}$ & + & - & + & - \\
\hline$\alpha$-Ketoglutaric acid & - & - & + & - & + & - & + & - \\
\hline Propionic acid & - & - & + & - & + & - & + & - \\
\hline L-Glutamic acid & + & - & + & $\mathrm{w}$ & + & + & + & $\mathrm{w}$ \\
\hline Sucrose & + & + & + & - & + & - & - & - \\
\hline Glycerol & + & - & - & + & + & + & - & - \\
\hline L-Alanine & + & $\mathrm{w}$ & + & - & + & - & - & - \\
\hline L-Alanyl glycine & + & - & + & - & + & + & - & $\mathrm{w}$ \\
\hline DL- $\alpha$-Glycerol phosphate & + & - & - & + & + & + & - & - \\
\hline \multicolumn{9}{|l|}{ Fermentation of: } \\
\hline Amygdalin & + & + & - & - & - & + & - & + \\
\hline Melibiose & - & + & + & - & - & - & + & - \\
\hline
\end{tabular}

(except R-40504) and nitrate reduction to nitrite; weakly positive for $\beta$-glucosidase activity (negative for $\mathrm{R}-40496^{\mathrm{T}}$, R-40498, R-40900 and R-40901). Negative for cystine arylamidase, $\alpha$-galactosidase, $\beta$-glucuronidase, $\alpha$-mannosidase, $\alpha$-fucosidase, arginine dihydrolase, urease and tryptophan deaminase enzyme activities, citrate utilization (except $\mathrm{R}-40498), \mathrm{H}_{2} \mathrm{~S}$ production, fermentation of inositol, sorbitol, rhamnose, melibiose and arabinose and reduction of nitrate to dinitrogen gas. All known strains utilize $\alpha$-cyclodextrin, dextrin, glycogen, Tweens 40 and 80, $N$-acetyl-D-glucosamine, cellobiose, D-fructose, $\alpha$-D-glucose, maltose, D-mannitol, D-mannose, psicose, sucrose, trehalose, methyl pyruvate, D-gluconic acid, DL-lactic acid, alaninamide, L-alanine, L-alanyl glycine, L-asparagine, L-aspartic acid, L-glutamic acid, glycyl L-aspartic acid, glycyl L-glutamic acid, L-threonine, inosine, uridine, thymidine, glycerol, DL- $\alpha$-glycerol phosphate, glucose 1-phosphate and glucose 6-phosphate. None of the known strains utilizes $\mathrm{N}$-acetyl-D-galactosamine, adonitol, L-arabinose, D-arabitol, i-erythritol, L-fucose, myo-inositol, lactose, lactose lactulose, melibiose, raffinose, L-rhamnose, turanose, xylitol, acetic acid, cis-aconitic acid, citric acid, formic acid, D-galactonic acid lactone, D-galacturonic acid, D-glucosaminic acid, $\beta$-hydroxybutyric acid, $\gamma$-hydroxybutyric acid, $p$-hydroxyphenylacetic acid, itaconic acid, $\alpha$-ketoglutaric acid, $\alpha$ ketovaleric acid, malonic acid, propionic acid, quinic acid, D-saccharic acid, sebacic acid, succinamic acid, L-histidine, L-leucine, L-ornithine, L-phenylalanine, L-pyroglutamic acid, DL-carnitine, $\gamma$-aminobutyric acid, phenylethylamine, putrescine, 2-aminoethanol or 2,3-butanediol. Utilization of the following compounds is variable (results in parentheses are from the type strain): D-galactose $(-)$, gentiobiose $(+)$, methyl $\beta$-D-glucoside $(-)$, D-sorbitol $(-)$, monomethyl succinate $(-), \alpha$-hydroxybutyric acid $(+)$, 
$\alpha$-ketobutyric acid $(+)$, succinic acid $(+)$, bromosuccinic acid $(+)$, glucuronamide $(+)$, D-alanine $(-)$, hydroxy-Lproline $(-)$, L-proline $(+)$, D-serine $(-)$, L-serine $(+)$ and urocanic acid $(+)$ (Supplementary Table S4). The fatty acid profiles of the eight known isolates are similar. The main cellular fatty acids are summed feature 3 (iso- $\mathrm{C}_{15: 0} 2-\mathrm{OH}$ and/or $\mathrm{C}_{16: 1} \omega 7 c$ ), $\mathrm{C}_{18: 1} \omega 7 c, \mathrm{C}_{16: 0}$ and $\mathrm{C}_{14: 0}$ (Supplementary Table S5). The following fatty acids are present in small amounts: summed feature $2\left(\mathrm{C}_{14: 0} 3-\mathrm{OH}\right.$ and/or iso$\mathrm{C}_{16: 1} \mathrm{I}$, an unidentified fatty acid with an equivalent chainlength of 10.928 and/or $\left.\mathrm{C}_{12: 0} \mathrm{ALDE}\right), \mathrm{C}_{12: 0} 3-\mathrm{OH}, \mathrm{C}_{12: 0}$, iso- $\mathrm{C}_{16: 0}, \mathrm{C}_{17: 0,}, \mathrm{C}_{17: 1} \omega 8 c$, iso- $\mathrm{C}_{17: 0}$ and iso- $\mathrm{C}_{13: 0}$. The DNA $\mathrm{G}+\mathrm{C}$ content of the type strain is $45.8 \mathrm{~mol} \%$; the range for the eight known strains is $45.2-46.0 \mathrm{~mol} \%$.

The type strain, R-40496 ${ }^{\mathrm{T}}\left(=\mathrm{LMG} 25430^{\mathrm{T}}=\mathrm{CAIM} 1816^{\mathrm{T}}\right)$, was isolated from mucus of the endemic coral Mussismilia hispida in the São Sebastião channel, SP, Brazil. Other strains are detailed in Table 1.

\section{Acknowledgements}

The authors acknowledge grants from FAPERJ, FAPESP, CNPq and IFS. L. A. C. acknowledges a PhD scholarship provided by CNPq. The BCCM/LMG Bacteria Collection is supported by the Federal Public Planning Service-Science Policy, Belgium. We thank Katrien Engelbeen (LMG/BCCM), Stefanie Van Trappen (LMG/BCCM), Alvaro Migotto (CEBIMAR-USP), Bruno Gomez-Gil and Cristiane C. Thompson for technical assistance and valuable comments.

\section{References}

Alsina, M. \& Blanch, A. R. (1994). A set of keys for biochemical identification of environmental Vibrio species. J Appl Bacteriol 76, 79-85.

Alves, N., Jr, Silva, B. S. O., Maia Neto, O. S., Moura, R. L., FranciniFilho, R. B., Castro, C. B., Paranhos, R., Bitner-Mathé, B. C., Kruger, R. H. \& other authors (2010). Diversity and pathogenic potential of vibrios isolated from Abrolhos Bank corals. Environ Microbiol Rep 2, 90-95.

Baumann, P. \& Baumann, L. (1984). Genus II. Photobacterium Beijerinck 1889, $401^{\mathrm{AL}}$. In Bergey's Manual of Systematic Bacteriology, vol. 1, pp. 539-545. Edited by N. R. Krieg \& J. G. Holt. Baltimore: Williams \& Wilkins.

Baumann, P. \& Schubert, R. H. W. (1984). Family II. Vibrionaceae Véron 1965, 5245 ${ }^{\mathrm{AL}}$. In Bergey's Manual of Systematic Bacteriology, vol. 1, pp. 516-517. Edited by N. R. Krieg \& J. G. Holt. Baltimore: Williams \& Wilkins.

Beaz Hidalgo, R., Cleenwerck, I., Balboa, S., Prado, S., De Vos, P. \& Romalde, J. L. (2009). Vibrio breoganii sp. nov., a non-motile, alginolytic, marine bacterium within the Vibrio halioticoli clade. Int $J$ Syst Evol Microbiol 59, 1589-1594.

Cervino, J. M., Thompson, F. L., Gomez-Gil, B., Lorence, E. A., Goreau, T. J., Hayes, R. L., Winiarski-Cervino, K. B., Smith, G. W., Hughen, K. \& Bartels, E. (2008). The Vibrio core group induces yellow band disease in Caribbean and Indo-Pacific reef-building corals. J Appl Microbiol 105, 1658-1671.

Chimetto, L. A., Brocchi, M., Thompson, C. C., Martins, R. C. R., Ramos, H. B. \& Thompson, F. L. (2008). Vibrios dominate as culturable nitrogen-fixing bacteria of Brazilian coral Mussismilia hispida. Syst Appl Microbiol 31, 312-319.
Chimetto, L. A., Brocchi, M., Gondo, M., Thompson, C. C., GomezGil, B. \& Thompson, F. L. (2009). Genomic diversity of vibrios associated with the Brazilian coral Mussismilia hispida and its sympatric zoanthids (Palythoa caribaeorum, Palythoa variabilis and Zoanthus solanderi). J Appl Microbiol 106, 1818-1826.

Dorsch, M., Lane, D. \& Stackebrandt, E. (1992). Toward a phylogeny of the genus Vibrio based on 16S rRNA sequences. Int J Syst Bacteriol 42, 58-63.

Eck, R. V. \& Dayhoff, M. O. (1966). Atlas of Protein Sequence and Structure. Silver Springs, MD: National Biomedical Research Foundation.

Ezaki, T., Hashimoto, Y. \& Yabuuchi, E. (1989). Fluorometric deoxyribonucleic acid-deoxyribonucleic acid hybridization in microdilution wells as an alternative to membrane filter hybridization in which radioisotopes are used to determine genetic relatedness among bacterial strains. Int J Syst Bacteriol 39, 224-229.

Farmer, J. J., III, Janda, J. M., Brenner, F. W., Cameron, D. N. \& Birkhead, K. M. (2005). Genus I. Vibrio Pacini 1854, $411^{\mathrm{AL}}$. In Bergey's Manual of Systematic Bacteriology, 2nd edn, vol. 2B, pp. 494-546. Edited by D. J. Brenner, N. R. Krieg, J. T. Staley \& G. M. Garrity. New York: Springer.

Felsenstein, J. (1985). Confidence limits on phylogenies: an approach using the bootstrap. Evolution 39, 783-791.

Gomez-Gil, B., Soto-Rodríguez, S., García-Gasca, A., Roque, A., Vazquez-Juarez, R., Thompson, F. L. \& Swings, J. (2004). Molecular identification of Vibrio harveyi-related isolates associated with diseased aquatic organisms. Microbiology 150, 1769-1777.

Gomez-Gil, B., Fajer-Avila, E., Pascual, J., Macián, M. C., Pujalte, M. J., Garay, E. \& Roque, A. (2008). Vibrio sinaloensis sp. nov., isolated from the spotted rose snapper, Lutjanus guttatus Steindachner, 1869. Int J Syst Evol Microbiol 58, 1621-1624.

Goris, J., Suzuki, K., De Vos, P., Nakase, T. \& Kersters, K. (1998). Evaluation of a microplate DNA-DNA hybridization method compared with the initial renaturation method. Can J Microbiol 44, 1148-1153.

Huys, G., Vancanneyt, M., Coopman, R., Janssen, P., Falsen, E., Altwegg, M. \& Kersters, K. (1994). Cellular fatty-acid composition as a chemotaxonomic marker for the differentiation of phenospecies and hybridization groups in the genus Aeromonas. Int J Syst Bacteriol 44, 651-658.

Kovács, N. (1956). Identification of Pseudomonas pyocyanea by the oxidase reaction. Nature 178, 703.

Mellado, E., Moore, E. R. B., Nieto, J. J. \& Ventosa, A. (1996). Analysis of $16 \mathrm{~S}$ rRNA gene sequences of Vibrio costicola strains: description of Salinivibrio costicola gen. nov., comb. nov. Int J Syst Bacteriol 46, 817821.

Mesbah, M., Premachandran, U. \& Whitman, W. B. (1989). Precise measurement of the $\mathrm{G}+\mathrm{C}$ content of deoxyribonucleic acid by highperformance liquid chromatography. Int J Syst Bacteriol 39, 159-167.

Noguerola, I. \& Blanch, A. R. (2008). Identification of Vibrio spp. with a set of dichotomous keys. J Appl Microbiol 105, 175-185.

Olson, N. D., Ainsworth, T. D., Gates, R. D. \& Takabayashi, M. (2009). Diazotrophic bacteria associated with Hawaiian Montipora corals: diversity and abundance in correlation with symbiotic dinoflagellates. J Exp Mar Biol Ecol 371, 140-146.

Rameshkumar, N., Fukui, Y., Sawabe, T. \& Nair, S. (2008). Vibrio porteresiae sp. nov., a diazotrophic bacterium isolated from a mangrove-associated wild rice (Porteresia coarctata Tateoka). Int J Syst Evol Microbiol 58, 1608-1615.

Reichelt, J. L. \& Baumann, P. (1973). Taxonomy of the marine, luminous bacteria. Arch Mikrobiol 94, 283-330. 
Ritchie, K. B. (2006). Regulation of microbial populations by coral surface mucus and mucus-associated bacteria. Mar Ecol Prog Ser 322, $1-14$.

Rosenberg, E., Koren, O., Reshef, L., Efrony, R. \& Zilber-Rosenberg, I. (2007). The role of microorganisms in coral health, disease and evolution. Nat Rev Microbiol 5, 355-362.

Saitou, N. \& Nei, M. (1987). The neighbor-joining method: a new method for reconstructing phylogenetic trees. Mol Biol Evol 4, 406425.

Sawabe, T., Fujimura, Y., Niwa, K. \& Aono, H. (2007a). Vibrio comitans sp. nov., Vibrio rarus sp. nov. and Vibrio inusitatus sp. nov., from the gut of the abalones Haliotis discus discus, $H$. gigantea, $H$. madaka and H. rufescens. Int J Syst Evol Microbiol 57, 916-922.

Sawabe, T., Kita-Tsukamoto, K. \& Thompson, F. L. (2007b). Inferring the evolutionary history of vibrios by means of multilocus sequence analysis. J Bacteriol 189, 7932-7936.

Tamura, K., Dudley, J., Nei, M. \& Kumar, S. (2007). MEGA4: molecular evolutionary genetics analysis (MEGA) software version 4.0. Mol Biol Evol 24, 1596-1599.

Thompson, F. L., Hoste, B., Thompson, C. C., Huys, G. \& Swings, J. (2001a). The coral bleaching Vibrio shiloi Kushmaro et al. 2001 is a later synonym of Vibrio mediterranei Pujalte and Garay 1986. Syst Appl Microbiol 24, 516-519.

Thompson, F. L., Hoste, B., Vandemeulebroecke, K. \& Swings, J. (2001b). Genomic diversity amongst Vibrio isolates from different sources determined by fluorescent amplified fragment length polymorphism. Syst Appl Microbiol 24, 520-538.

Thompson, F. L., Hoste, B., Vandemeulebroecke, K., Engelbeen, K., Denys, R. \& Swings, J. (2002a). Vibrio trachuri Iwamoto et al. 1995 is a junior synonym of Vibrio harveyi (Johnson and Shunk 1936) Baumann et al. 1981. Int J Syst Evol Microbiol 52, 973-976.

Thompson, F. L., Hoste, B., Thompson, C. C., Goris, J., Gomez-Gil, B., Huys, L., De Vos, P. \& Swings, J. (2002b). Enterovibrio norvegicus gen. nov., sp nov., isolated from the gut of turbot (Scophthalmus maximus) larvae: a new member of the family Vibrionaceae. Int J Syst Evol Microbiol 52, 2015-2022.

Thompson, F. L., Hoste, B., Vandemeulebroecke, K. \& Swings, J. (2003). Reclassification of Vibrio hollisae as Grimontia hollisae gen. nov., comb. nov. Int J Syst Evol Microbiol 53, 1615-1617.

Thompson, F. L., lida, T. \& Swings, J. (2004). Biodiversity of vibrios. Microbiol Mol Biol Rev 68, 403-431.

Thompson, F. L., Gevers, D., Thompson, C. C., Dawyndt, P., Naser, S., Hoste, B., Munn, C. B. \& Swings, J. (2005). Phylogeny and molecular identification of vibrios based on multilocus sequence analysis. Appl Environ Microbiol 71, 5107-5115.

Thompson, F. L., Gomez-Gil, B., Vasconcelos, A. T. R. \& Sawabe, T. (2007). Multilocus sequence analysis reveals that Vibrio harveyi and $V$. campbellii are distinct species. Appl Environ Microbiol 73, 42794285.

Urbanczyk, H., Ast, J. C., Higgins, M. J., Carson, J. \& Dunlap, P. V. (2007). Reclassification of Vibrio fischeri, Vibrio logei, Vibrio salmonicida and Vibrio wodanis as Alivibrio fischeri gen. nov., comb. nov., Aliivibrio logei comb. nov., Aliivibrio salmonicida comb. nov. and Aliivibrio wodanis comb. nov. Int J Syst Evol Microbiol 57, 2823-2829.

Wang, Y., Zhang, X.-H., Yu, M., Wang, H. \& Austin, B. (2010). Vibrio atypicus sp. nov., isolated from the digestive tract of the Chinese prawn (Penaeus chinensis, O’sbeck). Int J Syst Evol Microbiol 60, 2517-2523.

Willems, A., Doignon-Bourcier, F., Goris, J., Coopman, R., de Lajudie, P., De Vos, P. \& Gillis, M. (2001). DNA-DNA hybridization study of Bradyrhizobium strains. Int J Syst Evol Microbiol 51, 13151322.

Xu, X.-W., Wu, Y.-H., Wang, C.-S., Oren, A. \& Wu, M. (2009). Vibrio hangzhouensis sp. nov., isolated from sediment of the East China Sea. Int J Syst Evol Microbiol 59, 2099-2103.

Yoshizawa, S., Wada, M., Kita-Tsukamoto, K., Ikemoto, E., Yokota, A. \& Kogure, K. (2009). Vibrio azureus sp. nov., a luminous marine bacterium isolated from seawater. Int J Syst Evol Microbiol 59, 16451649 . 